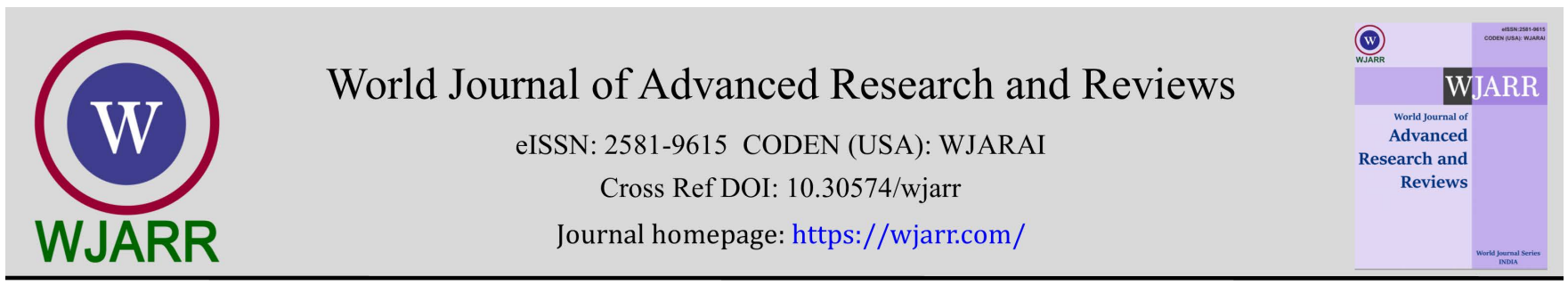

(RESEARCH ARTiClE)

Check for updates

\title{
Precancerous and cancerous lesions of the cervix at the Buea regional hospital- Cameroon
}

Andrew Tassang 1, ${ }^{*}$, R. Michael Brady 2, Tosin Yinka Akintunde 3, George Enow Orock 4, Ewane Theophile Palle 5, Angwi Enow Tassang ${ }^{3}$, Frederick Nchang Cho ${ }^{6}$, Thierry Tassang 7, Walters Ndaka ${ }^{8}$, Ncham Genesis Fointwen ${ }^{5}$, Ngum Fru Paulette ${ }^{9}$ and Daniel Okono Ndongo ${ }^{8}$

${ }^{1}$ Faculty of Health Sciences, University of Buea, Cameroon Buea Regional Hospital, Annex, Cameroon Atlantic Medical Foundation Hospital, Mutengene, Cameroon.

${ }^{2}$ Creighton University School of Medicine-Phoenix Arizona, USA.

${ }^{3}$ Department of sociology, School of Public Administration Hohai University, Nanjing, China.

${ }^{4}$ Faculty of Health Sciences, University of Buea, Cameroon Regional hospital Bafoussam, Cameroon.

${ }^{5}$ Buea Regional Hospital Annex SW Region-Cameroon, Faculty of Sciences, University of Buea-Cameroon.

${ }^{6}$ Global Health Systems Solutions, Cameroon Infectious Disease Laboratory, Faculty of Health Sciences University of Buea, Cameroon.

${ }^{7}$ Kumbo sub divisional Hospital NW Region, Kumbo- Cameroon.

${ }^{8}$ Buea Regional Hospital Annex SW Region-Cameroon.

${ }^{9}$ Department of Sociology and Anthropology Faculty of Social and Management Sciences, University of Buea, Cameroon Tiko health District, Cameroon.

World Journal of Advanced Research and Reviews, 2022, 13(03), 035-044

Publication history: Received on 20 January 2022; revised on 27 February 2022; accepted on 01 March 2022

Article DOI: https://doi.org/10.30574/wjarr.2022.13.3.0183

\begin{abstract}
The ectocervix is the part of the uterus which plunges into the apex of the vagina. A stratified squamous epithelium covers it. The endocervical canal, which establishes communication between the vagina and the endometrial cavity, is paved with a mucous secreting glandular epithelium. Because of the acidity of the vagina, these two epithelia undergo metaplasia. Some oncogenic factors do ignite instead of dysplasia. CIN1, CIN2, and CIN3 correspond to the premalignant transformation of $1 / 3,2 / 3$ and $3 / 3$ of these epithelia from the basal membrane. Invasive Cancer is when the latter is broken, and there is a penetration of the stroma by the malignant cells.
\end{abstract}

Methodology: A retrospective hospital-based study was conducted to establish the prevalence of various cervical malignancies at the Buea regional hospital. The registry of the pathology department was used. The study spanned from the 8th of March 2017 to the 16th of March 2021.

Results: The different cervical cancer types found were squamous cell carcinoma, small cell carcinoma, adenocarcinoma, and non-Hodgkin cervical cancer or lymphoma of the cervix. Their respective percentages were $73 \%$, $20.7 \%, 5.4 \%$ and $0.9 \%$.

Conclusion: Four different types of cancers were found in this study. Their prevalence was for squamous cell carcinoma (73\%), small cell carcinoma (20.7\%), adenocarcinoma (5.4\%), and non-Hodgkin carcinoma of the cervix (0.9\%).

\footnotetext{
${ }^{*}$ Corresponding author: Andrew Tassang; Email: andrewtassang@yahoo.com

Faculty of Health Sciences, University of Buea, Cameroon Buea Regional Hospital, Annex, Cameroon Atlantic Medical Foundation Hospital, Mutengene, Cameroon.

Copyright (C) 2022 Author(s) retain the copyright of this article. This article is published under the terms of the Creative Commons Attribution Liscense 4.0.
} 
Keywords: Cancer of the cervix; Squamous cell carcinoma; Small carcinoma; Adenocarcinoma; Non-Hodgkin carcinoma of the cervix

\section{Introduction}

The cervix is the caudal part of the uterus. It appears cylindrical measures about $3-4 \mathrm{~cm}$ in height and $1-3 \mathrm{~cm}$ in width and protrudes into the upper part of the vagina. Its diameter is smaller in nulliparous and larger in multiparous $[1,2$, $3]$. It is surrounded anteriorly posteriorly and laterally by fornices bearing the same descriptive names $[1,4,5]$. The cervix is divided into two. The portiovaginalis or ectocervix is covered by squamous epithelium. The supravaginal part which is not seen at the vaginal examination lies above the fornices.

The cervical stroma is made of collagen arterioles, venules the lymphatics channels and deep inside the stroma are glandular structures $[6,7,8]$.

An opening known as the external os is at the centre of the cervix. It may vary in form according to parity. The external os is surrounded by a sphincter that opens into the endocervical canal. A single layer of glandular epithelium surrounds this canal. This epithelium emits many branches into the stroma known as crypts. At the cranial part of this epithelium is the internal os surrounded by a sphincter bearing the same name $[1,2,9,10]$. The cervical canal establishes communication between the vagina and the endometrial cavity $[1,11]$.

The ectocervix is covered by a stratified squamous epithelium $[12,13,14]$.

The squamocolumnar junction (SCJ) line is where the columnar epithelium of the cervical canal and the squamous epithelium of the ectocervix meet. It is usually found at the level of the external os $[1,7,15]$. Oral contraceptives and pregnancy influence this position. Under the influence of hormones, the endocervical cells migrate above the columnarsquamous junction and find themselves on the portion vaginalis. These cells gradually transform themselves into squamous cells under the influence of the low PH of the vagina. This natural process is known as metaplasia. The SCJ finally retracts into the cervical canal at menopause. These changes are brought about by hormones $[1,2,15,16]$. The area between the initial SCJ, and the existing SCJ is the transformation zone (TZ). The epithelium in this area has undergone metaplasia. It is made of immature squamous cells. It is in the TZ that most dysplastic changes occur [1, 2, 3, 17]

\section{Metaplasia of the cervical epithelium}

Metaplasia is the replacement of one cell type by the other. It is a normal physiological process $[2,18,19]$.

The neonatal period, puberty and pregnancy are three major periods of metaplasia in an individual's life. The epithelium of the ectocervix is five layers thick, and each of them is subdivided into multiple layers [1, 2, 3, 22, 23]. The first layer is the basal layer and lies on the basement membrane, separating the epithelium from the underlying stroma. This layer is made of totipotent or reserve cells. The characteristics of these cells are that they are immature and they can transform themselves into any type of cells. They multiply at a very fast rate $[1,2,3,23,24]$. The $2^{\text {nd }}$ layer or prickle cells layer consists of cells larger than those of the basal layer. The $3^{\text {rd }}$ layer is made of glycogenated cells which are larger than those of the $2^{\text {nd }}$ layer. The $4^{\text {th }}$ layer consists of flat cells. The $5^{\text {th }}$ layer is the stratum corneum $[1,2,3]$. The metaplastic changes are from bottom to top. Beneath the glandular epithelium of the endocervix immature cells form and multiply rapidly, pushing the glandular cells into the cervical canal or vagina. The squamous cells eventually replace the glandular cells. This phenomenon starts at the level of the basal membrane and extends upward.

The transformation zone is the cervix area where both the columnar and the squamous cells at various stages do coexist. This area is between the former columnar- squamous junction and the present one [2, 24].

\section{Pathology of the cervix}

About $80-90 \%$ of Cancer of the cervix is made of squamous cells, and the rest from glandular cells $[1,11,18,25]$. Early cellular changes in metaplastic epithelia are viewed as the $1^{\text {st }}$ signs of dysplasia. These changes are referred to as cellular atypia $[24,26,27]$.

Human papilloma virus-infected cells follow a different developmental pathway leading to abnormal maturation and dysplasia [28, 29, 30]. 


\subsection{Cervical Intraepithelial Neoplasia (CIN) and Squamous carcinoma}

These lesions constitute about $80 \%$ of precancerous and cancerous lesions of the cervix (CC). They are sub graded into:

- $\quad$ Grade 1: In CIN 1, cells show hyperchromatic nuclei, pleomorphism, increased nuclear to cytoplasmic ratio, and lack of maturation. $1 / 3^{\text {rd }}$ of the thickness of the stratified squamous epithelium of the cervix is affected.

- $\quad$ Grade 2: In CIN 2, in addition to the abnormal cells described in CIN 1, numerous mitosis and bizarre mitotic figures are seen. These changes affect between $1 / 3$ to $2 / 3$ of the epithelial thickness.

- $\quad$ Grade 3: In CIN 3, severe dysplasia encompasses more than 2/3 of the epithelial thickness. Mitosis is abundant. This stage is known as carcinoma in situ [24, 31, 32].

\subsection{Invasive squamous cell carcinoma}

Invasive disease is diagnosed when the neoplastic cells break through the basement membrane of the squamous epithelium and infiltrate the stroma. These cells appear more bizarre as compared to those of the preinvasive stage [24, $31,32,33]$

\subsection{Adenocarcinoma}

This involves the glandular cells of the endocervix. Adenocarcinoma is often associated with squamous cell carcinoma in situ $[24,34]$. The cells in adenocarcinoma may show nuclear elongation, multinucleation and darkening. When the basement membrane is broken, and abnormal cells are found in the stroma, this is termed invasive adenocarcinoma $[24,34,35,36]$.

\subsubsection{Adenosquamous carcinoma}

About 3-5\% of CC are made of both types of cells [24, 37].

\subsubsection{Small cells and neuroendocrine carcinomas}

They are uncommon are very aggressive types of cancer [24, 38, 39]

The objective of this study is to describe the various types of cervical cancers diagnosed in the pathology department of the Buea Regional Hospital.

\section{Methodology}

\subsection{Study design, Population, and Data Collection}

A retrospective hospital-based study was conducted to investigate the prevalence of various forms of cervical Cancer aggregated in ages in Buea Regional Hospital, Buea Fako Division of South West Region, Cameroon. The study settings comprise medical departments and centres with specialists in surgical, pediatric, maternity, HIV/AIDs, Laboratory unit, and other key functions headed by surgeons, gynaecologists, and paediatricians [40].

\subsection{Data Collection}

Data explored in this retrospective study spanned over three years based on the registers of in and outpatients. We explored the record of the histopathology department in Buea Regional hospital from the 8th of March 2017 to the 16 th of March 2021.

\subsection{Ethical Consideration}

Ethical approval was granted by the ethical board of the faculty of medicine, University of Buea. Administrative clearance was received from the Director of the Buea Regional Hospital. The study strictly adhered to the Helsinki Declaration on the procedure for human research in methodology and interpretation of study evidence.

\subsection{Data Analysis}

Basic descriptive statistics were analyzed to present the distribution of varying cancer types reported within the time frame available data. The demographic variable "age" was used to appropriate the cervical cancer prevalence and frequency percentage among registered patients in the hospital. 


\section{Results}

Figure 1 represents the prevalence of premalignant and malignant lesions. Premalignant lesions; CIN 1, 2 and 3 jointly represented $51.2 \%$. The following CC had the following percentages, Invasive squamous cell carcinoma represented $33.8 \%$, small cells invasive Cancer represented 9.6\%, and Non-Hodgkin lymphoma represented $0.42 \%$ of all lesions.

The age distribution of the Invasive Squamous cell Carcinoma was reported in ages 31-71. In ages 51-60, a total of 30.8\% were diagnosed. A total of $9.8 \%$ of the reported Squamous cell invasive cancer was aged 71 and above (See Figure 2).

CIN1 was diagnosed among $5.6 \%$ of women ages $21-30$. The prevalence was higher in the following age groups: 41 $50(29.8 \%)$ and $51-60(28.4 \%)$. See figure 3.

CIN2 lesion was diagnosed in one woman aged 20 or less and $6.8 \%$ of women aged 21 - 30. It was most prevalent in ages 41 - 50 (45.5\%). See Figure 4.

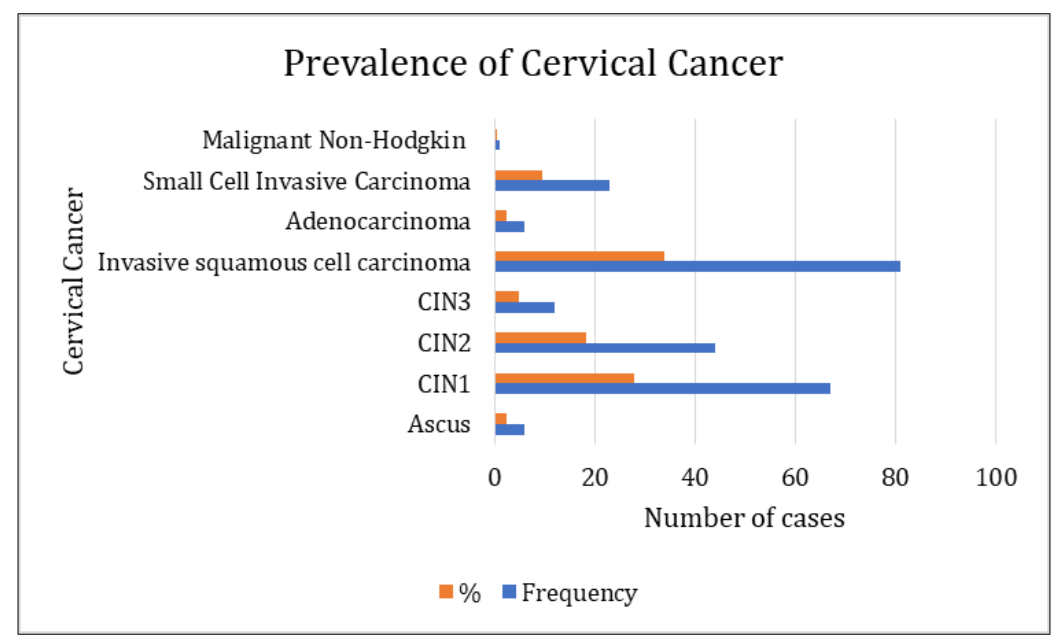

Figure 1 Prevalence of premalignant lesions and cervical cancer $(n=240)$

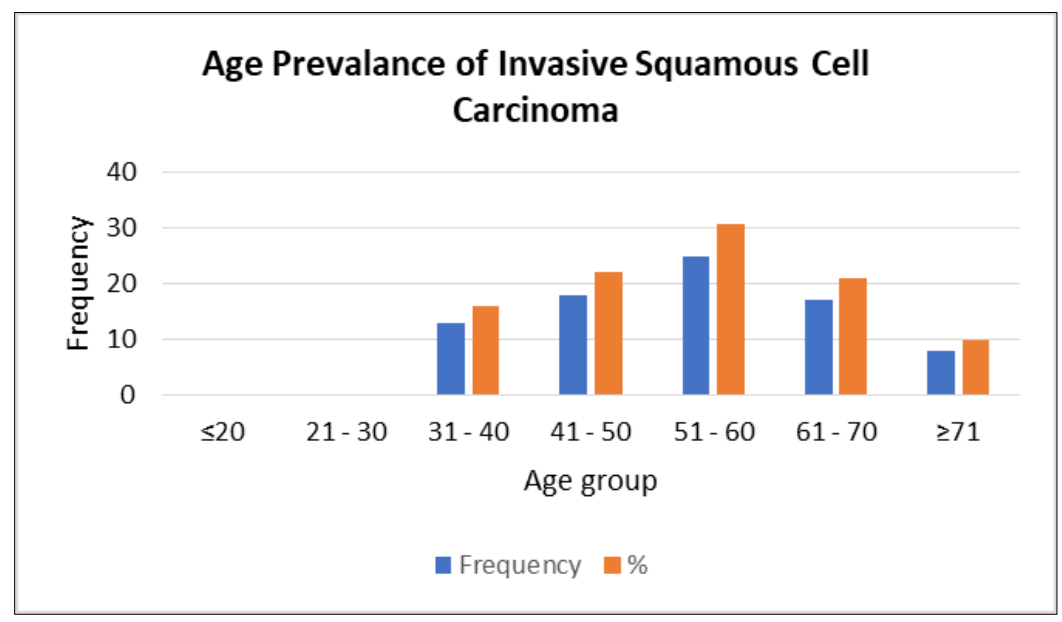

Figure 2 Age Prevalence of Invasive Squamous Carcinoma (n= 81) 


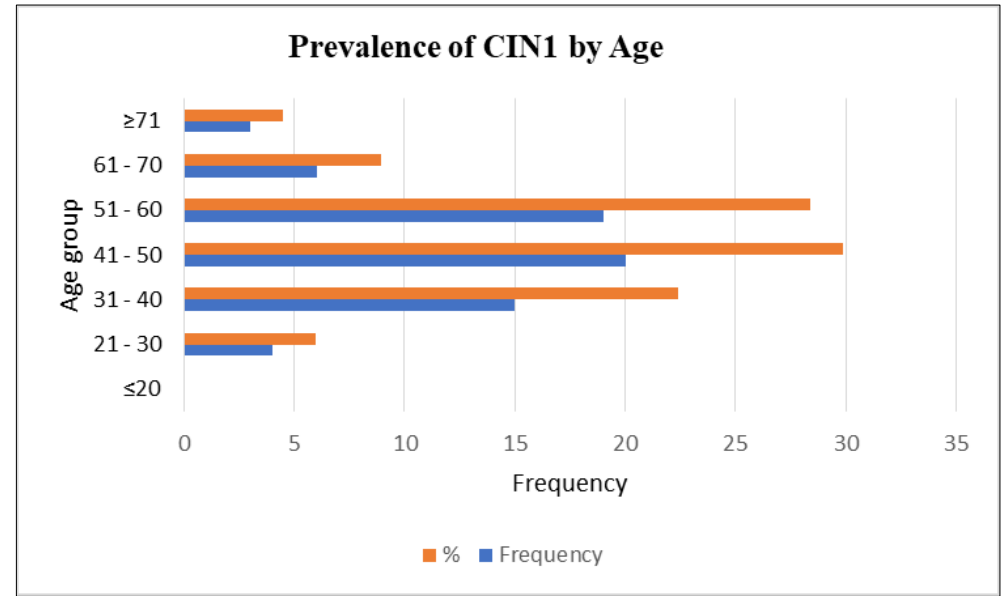

Figure 3 Age Prevalence of CIN1 (n=67)

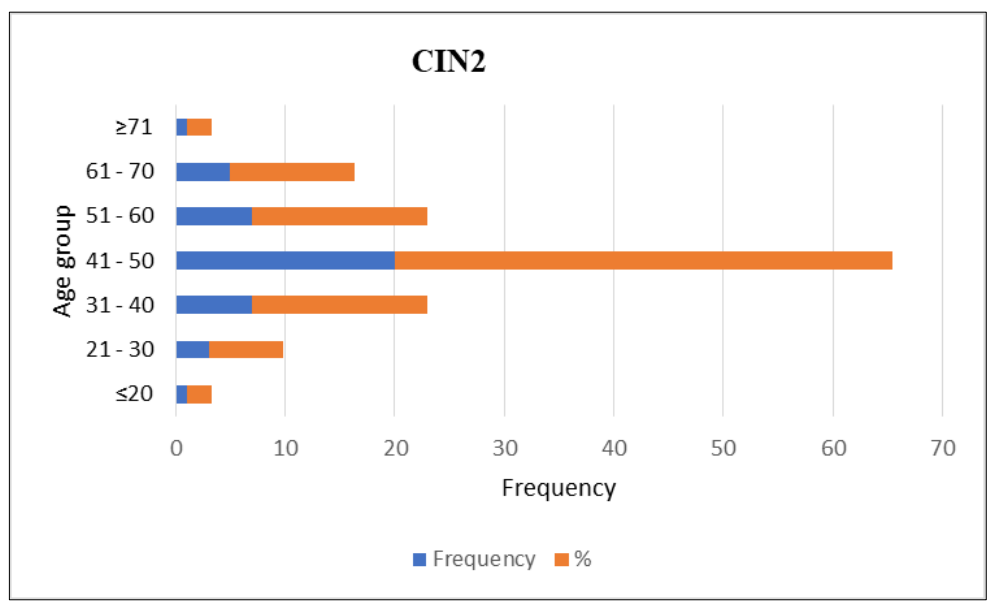

Figure 4 Age Prevalence of CIN2 (n= 44)

In Table 1, the other prevalent malignant cervical Cancer was small cell invasive carcinoma reported among 23 patients. Six women's results were atypical squamous cells of unspecified significance (ASCUS).

Table 1 Age Prevalence of other premalignant and malignant Cervical Cancer $(n=48)$

\begin{tabular}{|c|c|c|c|c|c|}
\hline $\begin{array}{c}\text { Age } \\
\text { Group }\end{array}$ & $\begin{array}{c}\text { ASCU } \\
\text { S }\end{array}$ & $\begin{array}{c}\text { CIN } \\
\mathbf{3}\end{array}$ & $\begin{array}{c}\text { Adenosquamous } \\
\text { Carcinoma }\end{array}$ & $\begin{array}{c}\text { Small Cell Invasive } \\
\text { Carcinoma }\end{array}$ & $\begin{array}{c}\text { Malignant } \\
\text { Non-Hodgkin }\end{array}$ \\
\hline$\leq 20$ & & & & & \\
\hline $21-30$ & 1 & & & 6 & \\
\hline $31-40$ & & & & 5 & \\
\hline $41-50$ & 2 & 5 & 2 & 3 & 1 \\
\hline $51-60$ & 2 & 2 & 3 & 5 & \\
\hline $61-70$ & 1 & 5 & & 3 & 1 \\
\hline$\geq 71$ & & & 1 & 23 & \\
\hline Total & 6 & 12 & 6 & & \\
\hline
\end{tabular}




\section{Discussion}

Cervical Cancer can be prevented using primary, secondary and tertiary methods. The primary techniques are; abstinence, mutual fidelity, use of condoms, and vaccination $[41,42]$. The secondary methods are screening tests and immediate treatment of precancerous lesions. They include the visual inspection methods; visual inspection with 3-5\% acetic acid (VIA) / visual inspection with Lugol iodine (VILI), Pap smear and, HPV DNA testing. About 80\% of CC can be prevented by these screening tests [43]. The tertiary methods are made of early treatment of precancerous lesions. They are cryotherapy, cold knife conization, and loop electrical excision procedure (LEEP) [44, 45, 46, 47].

Despite all these preventive methods above, in our study, the majority of patients $111 / 240(46.25 \%)$ received were diagnosed with invasive CC. Squamous cell carcinoma, with a total of 81 cases, represented $73 \%$ of invasive cancers of the cervix. This proportion falls in line with the findings of many authors, who classify Squamous Epithelial Cancer as the most common type of invasive Cancer of the cervix with a percentage of $70-80 \%[48,49,50]$. Women present themselves late when the tumour is at the malignant (64 falls to 49 and so on) stage. These findings are not different from what is reported in the literature [ 50,51,52,53]. Many reasons could account for late diagnosis. In the general population, there is poor knowledge and awareness of CC [54, 55, 56, 57]. Added to this, the economic and structural weaknesses of the health sector of middle- and low-income countries make it difficult to fight against CC. Most screening campaigns are pilot exercises. Specialized health facilities for CC, equipment and trained personnel for prevention and treatment of CC are lacking $[58,59,60]$.

In our study, the spike of occurrence of squamous cell carcinoma occurred between 51-60 years old, followed by the 41-50 years age group. This is slightly at variant with the works of many authors who put the spike at between 41 to 50 years $[60,61,62]$.

The endocervical canal is covered by a mucous producing epithelium and is the siege of adenocarcinoma. Out of 111 cases of CC in this study, adenocarcinoma, with a total of 6 cases, represent $5.40 \%$. Our findings are lower from the what is generally reported in literature $10-20 \%[63,64,65]$.

We had 23 cases of small cell neuroendocrine invasive carcinoma, representing $20.7 \%$. This proportion is in contrast to the $2 \%$ generally reported in the literature. This discrepancy raises the question: could our community have a higher rate of HPV18 infection?

The mean age of occurrence of small cells neuroendocrine carcinoma of the cervix is 45 years, according to literature. This is in accordance with our findings $[66,67,68,69]$.

One case of malignant non-Hodgkin CC was reported in this study. The common sites of implantation of extranodal implantation of non-Hodgkin disease are the gastrointestinal tract and the skin. However, cervical implantation is possible. The general literature puts the incidence of non-Hodgkin CC at less than $0.5 \%$, which is not very different from the $0.9 \%$ reported by this study [70]. The median age of occurrence as reported in the literature is around 44 years but could span 27 to 80 years. In this study, the lone case we had is between 51-60 years age range [71].

\section{Conclusion}

In this population, squamous carcinoma, with $73 \%$ of all malignancies, is the most common type of CC. Small cell neuroendocrine cancer compromised a higher proportion of cases in this group than earlier reports, at $20.7 \%$. Other types included adenocarcinoma (5.4\%), and an uncommon extranodal type of CC known as non-Hodgkin cervical Cancer or cervical lymphoma $(0.8 \%)$.

\section{Compliance with ethical standards}

\section{Acknowledgments}

We wish to thank all the staffs and students of the pathology department of the Buea Regional Hospital for their individual contribution towards the writing of this article.

\section{Disclosure of conflict of interest}

Authors have declared that no competing interests exist. 


\section{Statement of ethical approval}

All ethical procedures, the study adhered to Helsinki Declaration and the research procedure by the global ethical standard.

\section{Informed consent}

All participants in the survey gave verbal inform consent to participate in the research, and their information was treated with the utmost confidentiality. When samples were being collected for analysis, patients were informed that, their results could be used for studies. They all gave their verbal consent.

\section{Disclaimer}

The data used in this study are commonly and predominantly what we use in research in our country. Our aim is to advance knowledge.

\section{References}

[1] Alex Ferenczy. Anatomy and Histology of the Cervix 157 genital tract with emphasis on problems of differential tumor diagnosis. Pathol Res Pract. n.d;179

[2] Feldman D, Romney SL, Edgcomb J, Valentine T. Ultrastructure of normal, metaplastic and abnormal human uterine cervix: Use of montages to study the topographical relationship of epithelial cells. Am J Obstet Gynecol. 1984; 150: 573.

[3] Friedrich ER. The normal morphology and ultrastructure of the cervix. In: Blandau RJ, Moghissi KS, editors. The biology of the cervix. Chicago: University of Chicago Press; 1973. p. $79-102$.

[4] Franke W., Moll R, Achtstaetter T, Kuhn C. Cell typing of epithelial and carcinomas of the female genital tract using cytoskeletal proteins as markers. In: Peto R, editor. Banbury Reports 21, cervical Cancer. 1986. p. 121-44.

[5] Robboy SJ, Taguchi O, Cunha R. Normal development of the human female reproductive tract and alterations resulting from experimental exposure to diethylstilbesterol. Hum Pathol. 1982; 13: 190.

[6] Gould RR, Barter RA, Papadimitriou JM. An ultra-structural, cytodynamical and autoradiographic study of the mucous membrane of the human cervical canal with reference to subcolumnar cells. Am J Pathol. 1979; 95: 1.

[7] Fetissof F, Berger G, Dubois MP. Endocrine cells in the female genital tract. Histopathology. 1985;9(133).

[8] Fand SD. The histochemistry of human cervical epithelium. In: Blandau RJ, Moghissi KS, editors. The biology of the cervix. Chicago: University of Chicago Press; 1973. p. 103-24.

[9] Fand SB. The histochemistry of human cervical epithelium. In: Blandau RJ, Moghissi KS (eds) The biology of the cervix. Chicago, University of Chicago Press. 1973; 103-24

[10] Averette HE, Weinstein GD, Frost P. Autoradio-graphic analysis of cell proliferation kinetics in human genital tissues. I. Normal cervix and vagina. Am J Obstet Gynecol. 1970; 108: 8.

[11] Coppleson M, Pixley E, Reid B. Colposcopy; A scientific and practical approach to the cervix in health and disease. Charles CT, editor. Springfield Ill; 1971.

[12] Oyervides-Muñoz MA, Pérez-Maya AA, Rodríguez-Gutiérrez HF, Gómez-Macias GS, Fajardo-Ramírez OR, Treviño V, Garza-Rodríguez ML. Understanding the HPV integration and its progression to cervical cancer. Infection, Genetics and Evolution. 2018; 61: 134-144.

[13] Priebe AM. 2012 cervical cancer screening guidelines and the future role of HPV testing. Clinical Obstetrics and Gynecology. 2013; 56(1): 44-50.

[14] WHO. WHO guidelines for screening and treatment of precancerous lesions for cervical cancer prevention: supplemental material: GRADE evidence-to-recommendation tables and evidence profiles for each recommendation. World Health Organisation; 2013.

[15] Jin XW, Lipold L, Foucher J, Sikon A, Brainard J, Belinson J, Rothberg MB. Cost-Effectiveness of Primary HPV Testing, Cytology and Co-testing as Cervical Cancer Screening for Women Above Age 30 Years. Journal of General Internal Medicine. 2016; 31(11): 1338-1344. 
[16] Warhol MJ, Antonioli DA, Pinkus G S. Immunoperoxidase staining for involucrin: A potential diagnostic aid in cervicovaginal pathology. Human Pathology. 1982;13(12):1095-9.

[17] Moll R, Levy R, Czernobilsky B, Hohlweg-Majert P, et al. Cytokeratins of normal eptihelia and some neoplasms of the female genital tract. Lab Invest. 1983; 49: 599.

[18] Sigurdsson K, Sigvaldason H. Longitudinal trends in cervical histological lesions (CIN 2-3 ): a 25-year overview Acta Obstet Gynecol Scand. 2006; 85(3): 359-365.

[19] Koh WJ, Abu-Rustum NR, Bean S, Bradley K, Campos SM, Cho KR, Scavone JL. Cervical Cancer, version 3.2019, NCCN clinical practice guidelines in oncology. Journal of the National Comprehensive Cancer Network. 2019; 17(1): 64-84.

[20] Zidi S, Sghaier I, Gazouani E, Mezlini A, Yacoubi-Loueslati B. Evaluation of Toll-Like receptors 2/3/4/9 gene polymorphisms in cervical cancer evolution. Pathol Oncol Res. 2016; 22: 323-330.

[21] Fujiki H. Gist of Dr. Katsusaburo Yamagiwa's papers entitled 'Experimental study on the pathogenesis of epithelial tumors' (I to VI reports). Cancer Sci. 2014; 105: 143-149.

[22] Koss LG. Diagnostic cytology and its histopathologic bases. 3rd ed. Philadelphia: J.B. Lippincott; 1979.

[23] Chretian FC, Gernigon C, David G, Psychoyos A. The ultrastructure of human cervical mucus under scanning electron microscopy. Fertil Steril. 1973; 24: 746.

[24] Micheal SB. Colposcopy of the Cervix, Vagina, and Vulva, A comprehensive Textbook. Mosby

[25] Fontham ET, Wolf AM, Church TR, Etzioni R, Flowers CR, Herzig A, Smith RA. Cervical cancer screening for individuals at average risk: 2020 guideline update from the American Cancer Society. CA: A Cancer Journal for Clinicians. 2020; 70(5): 321-346.

[26] Bixel K, Denlinger N, Marsh L, Quick A, Salani R. Primary chemoradiation for the treatment of locally advanced cervical Cancer: Impact of treatment location and time on outcomes. Gynecologic Oncology. 2016; 141: 152.

[27] Eskander RN, Tewari KS. Chemotherapy in the treatment of metastatic, persistent, and recurrent cervical Cancer. Current Opinion in Obstetrics and Gynecology. 2014; 26(4): 314-321.

[28] Wright TC, Stoler MH, Behrens CM, Sharma A, Zhang G, Wright TL. Primary cervical cancer screening with human papillomavirus: end of study results from the ATHENA study using HPV as the first-line screening test. Gynecologic Oncology. 2015; 136(2): 189-197.

[29] C Neh Fru, Tassang Andrew, David Greenspan F. Nchang Cho, Mokake Martin, Joseph Livingstone, Tassang Thierry, P Ngum Fru, Nembulefac Derick. Vaccination Hesitancy: The Case of Cervical Cancer Vaccination in Fako Division, Cameroon. International Journal of TROPICAL DISEASE \& Health . 2021; 42(8): 32-43.

[30] Seck AC, Faye MA, Critchlow CW, et al. Cervical intraepithelial neoplasia and human papillomavirus infection among Senegalese women seropositive for HIV-1 or HIV-2 or seronegative for HIV Int J STD AIDS. 1994; 5(3): 189-193.

[31] Matsuo K, Machida H, Mandelbaum RS, Konishi I, Mikami M. Validation of the 2018 FIGO cervical cancer staging system. Gynecologic oncology. 2019; 152(1): 87-93

[32] World Health Organization. WHO guidelines for screening and treatment of precancerous lesions for cervical cancer prevention. World Health Organization. 2013

[33] Bruni L, Diaz M, Castellsagué X, Ferrer E, Bosch FX, de Sanjosé S. Cervical human papillomavirus prevalence in 5 continents: Meta-analysis of 1 million women with normal cytological findings. J Infect Dis. 2010; 202: 17891799.

[34] International Collaboration of Epidemiological Studies of Cervical Cancer. Comparison of risk factors for invasive squamous cell carcinoma and adenocarcinoma of the cervix: Collaborative reanalysis of individual data on 8, 097 women with squamous cell carcinoma and 1, 374 women with adenocarcinoma from 12 epidemiological studies. Int J Cancer. 2007; 120: 885-891.

[35] Jacobson G, Chuang L, Pankow M. Improving quality of care and timely access to radiation therapy for patients with invasive cervical Cancer at the National Cancer Institute Paraguay. Gynecol Oncol Rep. 2018; 25: 82-86.

[36] Boardman CH, Matthews KJ, Windle ML, Braden C D, Sonoda Y. Cervical cancer staging. Medscape. :2013. 
[37] Ferlay J, Soerjomataram I, Rajesh D, Sultan E, Colin M, Marise R, et al. Cancer incidence and mortality worldwide: sources, methods and major patterns in GLOBOCAN 2012. International Journal of Cancer. 2014;136(5).

[38] Ferlay J, Colombet M, Soerjomataram I, et al. Estimating the global cancer incidence and mortality in 2018: GLOBOCAN sources and methods. Int J Cancer. 2019; 144: 1941-1953.

[39] Torre LA, Bray F, Siegel RL, Ferlay J, Lortet-Tieulent J, Jemal A. Global cancer statistics, 2012. CA Cancer J Clin. 2015; 65: 87-108.

[40] The Buea Regional Hospital [Internet]. Available from: http://www.all-about-cameroon.com/the-buea-regionalhospital.html

[41] WHO. International Agency for Research on Cancer, World Health Organization. Cancer fact sheets: Cervix uteri. World Health Organisation; 2019.

[42] Cunningham MS, Davison C, Aronson KJ. HPV vaccine acceptability in Africa: a systematic review. Prev Med. 2014; 69: 274-9.

[43] Hopkins TG, Wood N. Female human papillomavirus (HPV) vaccination: Global uptake and the impact of attitudes. Vaccine. 2013;31(13): 1673-9.

[44] Gaffikin L, Blumenthal PD, Emerson M, Limpaphayom K. Royal Thai college of obstetricians and gynaecologists (RTCOG)/JHPIEGO corporation cervical cancer prevention group [corrected]. Safety, acceptability and feasibility of a single-visit approach to cervical-cancer prevention in rural Thailand: A demonstration project. Lancet Lond Engl. 2003; 361(9360): 814-20.

[45] Blumenthal PD, Gaffikin L, Deganus S, Lewis R, Emerson M, Adadevoh S. Cervical cancer prevention: Safety, acceptability and feasibility of a single-visit approach in Accra, Ghana. Am J Obstet Gynecol. 2007; $196(4): 407$. e1-407.e9.

[46] Castro W, Gage J, Gaffikin L, Sellors J, Sherris J. Effectiveness, safety and acceptability of cryotherapy: a systematic literature review. 2003.

[47] Apgar BS, Kaufman AJ, Bettcher C, Parker-Featherstone E. Gynecologic procedures: Colposcopy, treatments for cervical intraepithelial neoplasia and endometrial assessment. Am Fam Physician. 2013; 87(12): 836-43.

[48] Watson M, Saraiya M, Benard V, Coughlin SS, Flowers L, et al. Burden of cervical Cancer in the United States, 19982003. Cancer. 2008; 113: 2855-64.

[49] Momenimovahed Z, Salehiniya H. Incidence, mortality and risk factors of cervical Cancer in the world. 2017; 4(12): 1795-1811.

[50] Tassang A, Nembulefack D, Orock GE, Folefac L, Ndakason W, Ncham G, Fru PN. Cervical Cancer Screening in a Low - Resource Setting : Buea-Cameroon. 2020; 3(3): 47-55.

[51] Franco EL, Duarte-Franco E, Ferenczy A. Cervical cancer: Epidemiology, prevention and the role of human papillomavirus infection. CMAJ. 2001; 164: 1017-25.

[52] Tota JE, Chevarie-Davis M, Richardson LA, Devries M, Franco EL. Epidemiology and burden of HPV infection and related diseases: Implications for prevention strategies. Prev Med. 2011; 53(1): 12-21.

[53] Sankaranarayanan R, Budukh AM, Rajkumar R. Effective screening programmes for cervical Cancer in low- and middle-income developing countries. Bull World Health Organ. 2001; 79: 954-962.

[54] Fru CN, Tassang AN, Cho FN, Tassang T, Fru PN. Socioeconomic determinants influencing cervical cancer screening in Buea: A cross-sectional study. International Journal of TROPICAL DISEASE \& Health. 2020; 41(11): $14-22$.

[55] Joshi M, Mishra SR. Cervical cancer screening in Nepal. Health Prospect Journal of Public Health. 2013; 12(1): 1820.

[56] Yamaguchi N, Tsukamoto Y, Shimoyama H, Nakayama K, Misawa S. Effects of peer education interventions aimed at changing awareness of cervical Cancer in nursing students. Niigata J Health Welf. 2011; 11: 32-42.

[57] Fru CN, Andrew T, Cho FN, Tassang T, Fru PN. Socioeconomic Determinants Influencing Cervical Cancer Screening in Buea : A Cross-Sectional Study. 2020; 41(11): 14-22.

[58] Kaku M, Mathew A, Rajan B. Impact of Socio-economic Factors in Delayed Reporting and Late-stage Presentation among Patients with Cervix Cancer in a Major Cancer Hospital in South India. 2008; 9: 589-594. 
[59] Enow-Orock G, et al. Gynecological Cancer Profile in the Yaounde Population, Cameroon. Clin Mother Child Health 2006; 3(1): 437-444.

[60] Wild CP, Stewart BW, Wild C. World cancer report 2014. 2014.

[61] Siegel RL, Miller KD, Jemal A. Cancer Statistics. CA Cancer J Clin. 2017; 67: 7-30. WHO. Cervical Cancer. World Health Organisation, editor. World Health Organisation; 2018.

[62] SEER data for 2003 to 2007 [Internet]. 2007. Available from: http://seer.cancer.gov/

[63] Watson M, Saraiya M, Benard V, Coughlin SS, Flowers L, et al. Burden of cervical Cancer in the United States, 19982003. Cancer. 2008; 113: 2855-64.

[64] Alfsen GC, Thoresen SO, Kristensen GB, et al. Histopathologic subtyping of cervical adenocarcinoma reveals increasing incidence rates of endometrioid tumors in all age groups: a population based study with review of all nonsquamous cervical carcinomas in Norway from 1966 to 1970, 1976 to 1980, and 1986 to 1990. Cancer. 2000; 89: 1291.

[65] Albores-Saavedra J, Larraza 0, Poucell S, Rodríguez Martínez HA. Carcinoid of the uterine cervix: additional observations on a new tumor entity. Cancer. 1976; 38: 2328.

[66] Albores-Saavedra J, Gersell D, Gilks CB, et al. Terminology of endocrine tumors of the uterine cervix: results of a workshop sponsored by the College of American Pathologists and the National Cancer Institute. Arch Pathol Lab Med. 1997; 121: 34.

[67] Atienza-Amores M, Guerini-Rocco E, Soslow RA, Park KJ, Weigelt B. Small cell carcinoma of the gynecologic tract: a multifaceted spectrum of lesions. Gynecol Oncol. 2014; 134: 410-8.

[68] Satoh T, Takei Y, Treilleux I. Gynecologic Cancer InterGroup (GCIG) consensus review for small cell carcinoma of the cervix. Int J Gynecol Cancer. 2014; 24(3): S102-8.

[69] Abeler VM, Holm R, Nesland JM, Kjørstad KE. Small cell carcinoma of the cervix. A clinicopathologic study of 26 patients. Cancer. 1994; 73: 672.

[70] I Carr, AS Hill, B Hancock, FE Neal. Malignant lymphoma of the cervix uteri: histology and ultrastructure, Journal of Clinical Pathology. 1976; 29(8): 680-686.

[71] HG Muntz, JA Ferry, D Flynn, AF Fuller Jr., HM Tarraza. Stage IE primary malignant lymphomas of the uterine cervix, Cancer. 1991; 68(9): 2023-2032. 